\title{
The Current Development Situation of Social Sports Instructors in Wuhan City and a Preliminary Study on Its Management Strategies
}

\author{
Guohua SHAO \\ Physical Education Institute of Inner Mongolia Normal University, Hohhot, Inner Mongolia, 010022, China
}

\begin{abstract}
The paper takes the social sports instructors at various levels in seven central city areas of Wuhan City as the main research object; and the literature review method, questionnaire investigation, expert interview and comparative analysis and other research methods are adopted in this paper; from the perspectives of qualitative and quantitative analysis, the current development situation of social sports instructors and the existing problems in Wuhan City are investigated. On the basis of this, the rational suggestions to improve the construction of social sports instructor team in Wuhan City are put forward, which provides reference for the development of social sports instructors in other areas.
\end{abstract}

KEYWORD: Social sports instructors; Current development situation; Management strategies

\section{INTRODUCTION}

As a new and special group, social sports instructors have played a very important role in organizing and carrying out a variety of sports activities, raising awareness of the mass sports activities, guiding the scientific fitness of different people, guiding the mass sports consumption and other aspects. And its behavior will affect the long-term development of mass sports in our country. We should clearly realize that it has obvious deficiencies no matter in its quantity, structure, quality and training system, and its organization structure and standard management. This paper analyzed and studied the basic behavior characteristics of the social sports instructors so as to find the existing problems and restricting factors, and put forward the rational suggestions to improve the construction of social sports instructor teams in Wuhan City, and therefore provide new ideas for the development of social sports instructors in other areas, which is conducive to the practicality and standardization development of social sports instructors in our country.

\section{RESEARCH METHODS}

\subsection{The literature review method}

The basic theories in sociology, management, the theory of physical education and other disciplines at home and abroad as well as a large number of data of management documents and other aspects from the state general administration of sports, the provincial sports bureau about social sports instructor management are investigated, which provides a solid theoretical basis for the analysis and discussion of this study.

\subsection{Expert interview method}

In this paper, as for the organization and management of social sports instructors and the operation condition and other problems in Wuhan City, the study visited related leaders of Mass Sports Department of Wuhan Sports Bureau, and extensively consulted with social sports experts.

\subsection{Questionnaire survey}

The questionnaires designed according to the research contents involved in the study were distributed on site by various City Sports Bureaus of Wuhan Municipal Bureau of sports, involving seven central areas in Wuhan city; 800 questionnaires in total were distributed, 800 questionnaires were taken back, the recovery rate was $100 \%$, in which, 795 effective questionnaire were taken back, the effective recovery rate was $99.375 \%$. 
3 RESEARCH RESULTS AND ANALYSIS

\subsection{Analysis of the main factors affecting Wuhan social sports instructors Behaviors}

Table 1. the main factors affecting the behaviors of social sports instructors in Wuhan City

\begin{tabular}{|l|c|c|}
\hline Influencing factor & $\begin{array}{l}\text { Number } \\
\text { of people }\end{array}$ & $\begin{array}{l}\text { proportion of } \\
\text { the total ( \% ) }\end{array}$ \\
\hline 1. Unpaid or underpaid & 618 & 77.74 \\
\hline 2. Unclear guidance tasks and objects & 237 & 29.81 \\
\hline $\begin{array}{l}\text { 3.Inadequate professional knowledge } \\
\text { and skill level }\end{array}$ & 409 & 51.45 \\
\hline 4.Incomplete venues, facilities & 501 & 63.02 \\
\hline 5.Unstable participants team & 223 & 28.05 \\
\hline $\begin{array}{l}\text { 6.Not high degree of social } \\
\text { recognition }\end{array}$ & 315 & 39.62 \\
\hline $\begin{array}{l}\text { 7. Usually busy with their own work, } \\
\text { and have no time or effort }\end{array}$ & 89 & 11.19 \\
\hline $\begin{array}{l}\text { 8.Relationships with community } \\
\text { residents }\end{array}$ & 69 & 8.68 \\
\hline $\begin{array}{l}\text { 9.Inadequate degree of government } \\
\text { support }\end{array}$ & 312 & 39.25 \\
\hline 10.Others & 46 & 5.79 \\
\hline
\end{tabular}

Through the investigation of Wuhan City Social Sports Instructors, we can see that the behaviors of social sports instructors are affected to varying degrees by the external environment and the quality of their own, and thus having an impact on the effectiveness of the guidance and mentoring process. In which, social cognition and other factors play a major role, such as remuneration, social acceptance, their professional knowledge and skills, venue facilities, government support and other factors are in the top row.
We can say that the participation of social sports instructors in fitness activities during is not high in China, which is affected by many factors, such as in the aspects of certification and training, people's health awareness and recognition, the fitness guidance of social sports instructors' subjective and objective conditions and so on.

\subsection{The investigation results of the current situation of social sports instructors in Wuhan City}

\subsubsection{Willingness and motivation of the guidance}

We found from the investigation that 511 people $(64.28 \%)$ were willing to engage in the guidance of the social sports instructors; $17.86 \%$ of them would like to engage in it; $14.84 \%$ of the people expressed ambiguous attitude; $2.64 \%$ of people were less willing to, only $0.38 \%$ of people held the negative attitude. This requires relevant departments should strengthen the responsibility compulsory education of social sports instructors, and take effective measures to improve the enthusiasm of social sports instructors who work in the guidance. At present, most of the social sports instructors in Wuhan city are compulsory to guide, which is consistent with the lowest pay, their own exercise, top rank in entertainment in the questionnaire; Since there is no reward to obtain benefits, it is reasonable to spread knowledge and broaden social, hobbies, civic duty, and enrich experience as a guide; the career development ranking No. 10 reflects the immaturity of opportunity and environment for the career development of social sports instructors.

Table 2. Investigation of social sports instructors' motivation

\begin{tabular}{|c|c|c|c|c|c|c|c|c|c|c|}
\hline Reason & $\begin{array}{l}\text { Their own } \\
\text { exercise }\end{array}$ & $\begin{array}{l}\text { Interests and } \\
\text { hobbies }\end{array}$ & \begin{tabular}{|l|} 
Rich \\
experience
\end{tabular} & $\begin{array}{l}\text { Use of } \\
\text { leisure time }\end{array}$ & \begin{tabular}{|l} 
Broaden \\
social
\end{tabular} & $\begin{array}{l}\text { Duties of } \\
\text { a citizen }\end{array}$ & Worthiness & \begin{tabular}{|l}
$\begin{array}{l}\text { Other } \\
\text { reasons }\end{array}$ \\
\end{tabular} & $\begin{array}{l}\text { Getting } \\
\text { recognition }\end{array}$ & $\begin{array}{l}\text { Getting } \\
\text { paid }\end{array}$ \\
\hline Percentage (\%) & 19.25 & 14.09 & 12.81 & 11.19 & 9.31 & 8.43 & 7.42 & 7.17 & 6.92 & 4.78 \\
\hline Rank & 1 & 2 & 3 & 4 & 5 & 6 & 7 & 8 & 9 & 10 \\
\hline
\end{tabular}

From the work carried out by the current social sports instructors, the main service mode is mainly in the form of free services, accounting for $74.09 \%$, which embodies the volunteer service of social sports instructors in Wuhan city. $18.99 \%$ of people thought that they worked in the form of getting paid and free service; only $6.92 \%$ of people said they carried out social sports guidance in the form of getting paid.

\subsubsection{Frequency, time and place to guide}

For the guidance time, weekly guide times is 1-2 times, which accounted for $41.38 \%, 3-4$ times (accounting for 20.50\%), 5-6 times (accounting for $21.64 \%$ ), 7 times or above accounted for $16.48 \%$ (See Table 3). The guidance time of social sports instructors each time in Wuhan city is less than 1 hour (accounting for 23.02\%), 1-2 hours (accounting for $63.14 \%$ ), 2 hours or above accounted for $13.84 \%$ (See Table 4), this is basically in line with the current people's habit of exercise time, and can meet the basic needs of exercisers to accept guidance every time, but it to some extent can't meet the needs of the exercisers.

Table 3. Frequency of the guidance of social sports instructors in Wuhan City

\begin{tabular}{|l|c|c|c|c|}
\hline Frequency (times) & $1-2$ & $3-4$ & $5-6$ & $\geq 7$ \\
\hline Percentage (\%) & 41.38 & 20.50 & 21.64 & 16.48 \\
\hline
\end{tabular}


Table 4. Guidance time of the social sports instructors each time in Wuhan City (unit: h)

\begin{tabular}{|l|c|c|c|}
\hline Time $(\mathrm{h})$ & $\leq 1$ & $1-2$ & $\geq 2$ \\
\hline Percentage (\%) & 23.02 & 63.14 & 13.84 \\
\hline
\end{tabular}

On one hand, due to the quickening rhythm of social life, ordinary citizens, especially people aged 30 to 50 are either lack of free time to go to the fitness activities, or their fitness consciousness is not strong. On the other hand, at present, the professional structure of the social sports instructors in Wuhan city is mostly part-time; their guidance time is given priority to free leisure time.

The guidance place of social sports instructors in Wuhan City is $39.12 \%$ of the places for morning and evening exercise, $23.27 \%$ of sports coaching center,
$7.04 \%$ of club, $3.77 \%$ of business fitness recreation and $26.8 \%$ of other places in turn. This showed the properties of residents' current activity site various, the activity places of most people are still concentrated in the park, the side of the road, without a normal activity site, and the lower proportion of club and business fitness places shows that at present, the development of the social sports instructors cannot keep up with the pace of development of market economy. It is noteworthy that the proportion of no formal activity places is considerable, which is related to the current imperfect qualification certification system of social sports instructor Wuhan City. It is also found that, there exist personnel who have no social Instructor Certificate; the order of the guidance is still quite chaotic.

Table 5. Guidance field distribution of social sports instructors in Wuhan

\begin{tabular}{|l|l|l|c|c|c|}
\hline Field & $\begin{array}{l}\text { Places for morning and } \\
\text { evening exercises }\end{array}$ & $\begin{array}{l}\text { Sports coaching } \\
\text { centers }\end{array}$ & Clubs & $\begin{array}{l}\text { Business fitness entertainment } \\
\text { facilities }\end{array}$ & Others \\
\hline Percentage (\%) & 39.12 & 23.27 & 7.04 & 3.77 & 26.8 \\
\hline
\end{tabular}

\subsubsection{Project and methods of the guidance}

As shown in Table 6, the guidance project frequency distribution selected by the respondents: Martial arts, aerobics and Taijiquan are still the first choice for people to conduct the exercise programs; this is obviously connected to the gender, age and occupation distribution of the participants, and it is found from the investigation, like most of the other provinces, exercisers are mainly the middle-aged and old people and women.

Table 6. project distribution of social sports instructor in Wuhan City

\begin{tabular}{|l|c|c|c|c|c|c|c|}
\hline Project & Martial arts & Taijiquan & Aerobics & Balls & swimming & Fitness equipment & Others \\
\hline Percentage (\%) & 20.75 & 18.74 & 19.75 & 15.60 & 8.18 & 6.04 & 11.57 \\
\hline Rank & 1 & 3 & 2 & 4 & 7 & 6 & 5 \\
\hline
\end{tabular}

\section{STANDARDIZED MANAGEMENT STRATEGIES}

\subsection{To give full play to the functions of government, and constantly optimize the structure of social sports instructors}

It is needed to enhance service awareness while strengthening government macro-management functions, and gradually transfer the management body, so that the social sports organization becomes the subject of social sports instructor management. And it is also needed to gradual establish an association of social sports instructors, which deals with training, assessment, auditing of qualifications, recommendation and dispatch of social sports instructors. The administrative departments for physical culture and sports in Wuhan City should provide policy and funding support for social sports instructors association, part of the funding should be transferred from the sports lottery welfare funds every year to the association of social sports instructors, it is needed to have the special funds of the social sports instructors, so as to promote the sustainable development of social sports instructors association. To develop and use the neighborhood social sports instructors, train sports backbone, organize sports teams, and progressively realize the management system of neighborhood sports network which depends on the function of street office.

\subsection{To carry out the related management regulations of social sports instructors, strengthen the cultivation of professional talents}

It is needed to develop the curriculum centering on the characteristics of the profession of social sports instructors in the social sports specialty of higher sports schools in Wuhan city, effectively construct the knowledge system of the major, and strengthen students' social practice ability through various forms of practice, so as to adapt to the need of the society. The management system of Wuhan social sports instructors should use the government macroeconomic regulation and control, base on 
social organization and management, rely on the society and the masses support, industry selfdiscipline management system of social sports instructors. Sports administrative departments are mainly responsible for management of the public welfare of social sports instructor, formulate corresponding laws, regulations and policies, improve macroeconomic regulation and control functions; approve the training institutions and social sports instructor qualification and approval; supervise the process of training and management; provide funding support for the development of social sports instructors; and set up information communication and contact between different social groups and institutions.

\subsection{To further improve the training system of social sports instructors, improve the employment rate}

It is needed to determine the training objectives and content according to different levels and projects of the social sports instructors in different categories. The training for the social sports instructor of exercise guidance should be targeted to increase technical training content, meet their real needs, set up the cultivation mechanism to meet the needs of social sports instructors for the era development, so as to guarantee the quality of social sports instructors in our country. It is needed to attach great importance to the quality of social sports instructors and the improvement of the employment rate, and the employment rate of social sports instructors currently is one of the "bottlenecks" which restricts the development of social sports instructors in Wuhan. It is needed to strengthen the service consciousness of social sports instructors, and the standard of service hours should be formulated for social sports instructors each year. To form a threelevel network management system of city, district (county), street (town) centering on Wuhan, the social sports instructor management should be incorporated into the duty of governments at all levels; carry out the graded responsibility system. Municipal Sports Bureaus are responsible for the macroeconomic management of social sports instructors in this city; the sports administration departments in the county level are responsible for comprehensive management of social sports instructors in the county; street and township is responsible for the daily management of social sports instructors in the region.

\section{CONCLUSIONS}

First, the main factors affecting the behaviors of social sports instructors in Wuhan are too low remuneration, low social acceptance; they are lack of professional knowledge and skills, the lack of venues and facilities, and inadequate government support is a major factor. Under the socialist market economy, it is needed to improve the remuneration of social sports instructors in Wuhan, standardize the management, strengthen the cultivation of social sports instructors practice ability, and continuously improve sports venues and facilities.

Second, the guidance motivation of social sports instructors in Wuhan shows a diversity trend, mainly in their exercise and hobbies; its service approach is the free service-oriented, supplemented by the paid service. Guidance projects are mainly martial arts, aerobics and Taijiquan; the guidance frequency is 12 times/ week, the guidance time is generally $1-2$ hours / times; the guidance places are mainly in the activity points for morning and evening exercises. Ways to guide the activities are mainly organized by individuals and streets.

Third, in order to promote the standardized development of social sports instructors in Wuhan, it is needed to continue to optimize the structure of social sports instructors, improve relevant laws and regulations of social sports instructor management, and improve service levels of social sports instructors.

Fourth, give full play to the responsibilities of the social sports instructors, further perfect the training system of social sports instructors in Wuhan city, strengthen social propaganda, enlarge the influence of social sports instructors, and perfect the incentive mechanism of the social sports instructors.

\section{REFERENCES}

[1] Zhou Songqing, He Ying, Hu Jianzhong, et.al. Comparison and Countermeasure on Current Situation of Social Sports Instructors between China and Japan. Journal of Capital Institute of Physical Education, 2013, 25(4): 309-312.

[2] Yan Shoufu, Li Siqi, Zhao Li. Current Development Situation of Social Sports Instructors in Beijing and Countermeasures Research. China Sports Science and Technology, 2010, 46(6):103-108. 